\title{
Party decline or social transformation? Economic, institutional and sociological change and the rise of anti-political-establishment parties in Western Europe
}

\author{
Fernando Casal Bértoa ${ }^{1, *}$ (iD and José Rama ${ }^{2}$ (D) \\ ${ }^{1}$ School of Politics and International Relations, University of Nottingham, University Park, Nottingham, UK and ${ }^{2}$ Department \\ of Political Economy, King's College London, London, UK \\ ${ }^{*}$ E-mail: fernando.casal.bertoa@nottingham.ac.uk
}

(Received 21 January 2020; revised 12 May 2020; accepted 12 May 2020; first published online 29 June 2020)

\begin{abstract}
The rise in support for anti-political-establishment parties (APEp), especially since the beginning of the 2008 Great Recession, has put democracy in peril. Some scholars have warned us about the negative implications the recent rise of APEp might have for the development of democracy in Western Europe. For that reason, it is important we begin to understand what generates APEp's electoral success. Drawing on a new comparative dataset that examines all Western European democracies from 1849 until 2017, the current article attempts to provide an explanation. In particular, our analyses examine three alternative explanations put forward by the literature: economic, institutional, and sociological. Our results show that it is not economic performance but both institutional and sociological change which together can help to understand the current wave of support for APEp.
\end{abstract}

Keywords: anti-political-establishment parties; populism; party system change; Great Recession; Western Europe

\section{Introduction}

Representative democracy in general, and traditional political parties in particular, is in crisis (Mair, 2013; Ignazi, 2017). Although this is nothing new (Ignazi, 1996; Gunther et al., 2002), the truth is that support for anti-political-establishment parties (APEp) is on the rise, especially since the beginning of the 2008 Great Recession (Norris and Inglehart, 2019; Kriesi and Pappas, 2015; Wolinetz and Zaslove, 2018), and has never been so high. Whereas, as shown elsewhere (Rama and Casal Bértoa, 2019: 11), after the Second World War the average level of electoral support for APEp was just $11 \%$, it almost doubled during the last decades. ${ }^{1}$ For example, only during the last years, APEp such as Alternative for Germany (AfD), the National Front, or the League (Lega) as well as the Five Stars Movement (M5S) have managed to shake the foundations of other traditionally consolidated democracies in Germany, France, and Italy, respectively.

APEp have even managed to get access to government in long-established Western European democracies such as Denmark or Norway. In most cases, they have done so as simple junior coalition partners (e.g., Austria, Belgium, Finland, and, most recently, Spain). In other cases (just two), they have managed not only to win parliamentary elections but also to form totally anti-political-establishment coalition governments: the first one in Greece, where the Coalition of the Radical Left (Syriza) joined forces with the national conservative, but also with

\footnotetext{
${ }^{1}$ The percentage of votes for APEp between 2010 and 2017 was as high as $20.7 \%$ (on average).
} 
Eurosceptic, Independent Greeks (ANEL) in 2015, and the second one, more recently (2018), in Italy between the populist M5S and the regionalist (also populist) Lega.

The recent electoral success of APEp in general, and far-right parties in particular, has raised important questions about the future of democracy in Western Europe (Mudde, 2019; Rama and Casal Bértoa, 2019). In fact, the rise of support for APEp (e.g., Communists, Fascists, and populists) has been traditionally associated with executive fragility (Powell, 1981), mass rioting (Lane and Ersson, 1994), systemic instability (Sartori, 1976), democratic backsliding (Enyedi, 2016), and, finally, democratic breakdown (Linz, 1978). In a similar vein, Foa and Mounk (2016) as well as Galston (2018) also pointed out how the recent success of populist/extreme parties (another type of APEp) has a negative effect on (liberal) democracy.

Given this strong and negative correlation between rise in support for APEp and democracy, especially its liberal (i.e., rule of law, minority rights and separation of powers) component (Mudde and Rovira Kaltwasser, 2018: 4), it is essential we try to understand the main factors behind APEp's success. Drawing on a new comparative dataset including all 20 Western European democracies since $1849,{ }^{2}$ the current article attempts to provide an explanation to the rise in electoral support for APEp. In particular, the article examines three alternative explanations traditionally put forward by the literature, namely, economic, institutional, and sociological. The main aim of the article is to see to what extent they are in contradiction or, on the contrary, complementary to each other.

The article proceeds as follows. The following section discusses the conceptualization and operationalization of the dependent variable and shows the evolution of support for APEp by country and over time. The third section looks at the literature on the determinants of support for APEp be they populist, radical, extreme and anti-systemic - and formulates various hypotheses. The fourth section presents the main independent variables as well as the various controls. The dataset and the methodology are introduced in the fifth section, while the sixth section presents the results. The article concludes with a summary of our main findings, containing also some reflections on what their implications might be for the future development of Western European party politics.

\section{APEp in Western Europe}

The concept of APEp is not universally accepted. Many scholars prefer to employ the term 'radical'(Funke et al., 2016), 'populist' (Norris and Inglehart, 2019), 'anti-system' (Zulianello, 2019), 'pariah' (van Spanje and van der Brug, 2007), 'extreme' (Carter, 2005), 'challenger' (Hobolt and Tilley, 2016), or 'protest' (Morlino and Raniolo, 2017) to refer to political parties sharing a clear anti-establishment character.

Trying to avoid this nominological confusion (Zulianello, 2019), and in order to capture all those parties that pose a challenge to democracy (independently of their populist character or not, their location - at the extremes or not - within the political spectrum, the way - discriminative or not - establishment parties treat them, etc.), we have decided to use the 'more comprehensive' (Schedler, 1996: 292) notion of APEp. In particular, and following Abedi's original definition, we consider that an APEp needs to present at the same time all of the following three characteristics:

(1) to perceive itself as a challenger to the parties that make up the political establishment;

(2) to assert that a fundamental divide exists between the political establishment and the people (implying that all establishment parties, be they in government or in opposition,

\footnotetext{
${ }^{2}$ While for France we start with the Second Republic, data for most continuous democracies only start at the beginning of the 20th century (e.g., Norway and Denmark) or after the First World War (see Table 1).
} 
are essentially the same); and (3) to challenge the status quo in terms of major policy issues and political system issues (2004: 12). ${ }^{3}$

In practice, however, our dataset includes most of the parties labeled by scholars as radical, populist, extreme, anti-immigration, and protest, as many of them also clearly fulfill all of Abedi's three criteria at the same time. ${ }^{4}$

A complete list of all the APEp ${ }^{5}$ for the elections included in our analyses can be found in Table A1 in the Online Appendix. For the 1945-2000 period, we accept Abedi's original list (2004: 143-150) as a valid roster of APEp. For the period after 2000, we rely on multiple sources (including both case- and medium-N studies), but especially on the following four works: Loomes (2011), van Kessel (2015), Kriesi and Pappas (2015), and Wolinetz and Zaslove (2018). For the period before 1945, and on top of multiple country-based works/datasets (e.g., Hanley, 2002; Karvonen, 1993; Vossen, 2003), we mostly based our coding on Berg-Schlosser and Mitchell (2000), Capoccia (2005) and Linz (1978).

Figure 1 shows the percentage of votes for APEp (our dependent variable) in 20 Western European democracies since the beginning of the 20th century. ${ }^{6}$ In agreement with the most recent literature, electoral support for this set of parties is on the rise (Norris and Inglehart, 2019; Hernández and Kriesi, 2016; Wolinetz and Zaslove, 2018). As it follows from the figure above, this is clearly the case all-over Western Europe, with just two exceptions,: namely, Malta and Switzerland. ${ }^{7}$

Furthermore, and following the conventional wisdom, most of the countries where APEp have been more successful are those affected by, among other factors, (1) economic downturn (e.g., Cyprus, Greece, and Iceland); (2) immigration (e.g., Germany, France, and The Netherlands); (3) corruption (e.g., Spain); or all these three at the same time (e.g., Italy).

On average, the percentage of votes for APEp in Western Europe during the last few years has exponentially increased: from around 17\% during the previous two decades (1990-2009) to more than $24 \%$ in the 2010s (2010-2017). To the point that more than the $40 \%$ of the elections with record levels of support for APEp held since 1950 have taken place only during the last decade. In fact, Western European APEp attract now 13\% more votes than in the 1960s, when party systems were considered to be 'frozen' (Lipset and Rokkan, 1967).

However, it is also important to note that in an important number of countries (i.e., Germany, Finland, France, Ireland, Italy, Norway, Switzerland, Portugal, and Spain), the election with the highest percentage of votes for APEp took place before the beginning of the 21st century. Moreover, it is also possible to observe in Figure 1 that in most consolidated European

\footnotetext{
${ }^{3}$ In essence, our definition of APEp is very close to the ideational approach of populism, characterized by: "1) a Manichean and moral cosmology; 2) the proclamation of the people as a homogenous and virtuous community; and 3) the depiction of 'the elite' as a corrupt and self-serving entity" (Hawkins and Rovira Kaltwasser, 2018: 3).

${ }^{4}$ Abedi (2004) uses the example of the Austrian Freedom Party (FPÖ) to shed some light regarding the classification of parties into the category of APEp. Thus, on his classification of APEp between 1945 and 1999, he argues that while FPÖ fits all the criteria from 1945 until 1970 and again from 1986, it could not be considered an APEp between 1971 and 1985. Thus, the anti-political-establishment status of a party can change over time. Similarly, and more recently, one could consider Podemos an APEp until 2019, but not after it joined the cabinet in Spain. Additionally, it is important to clarify that while, as Schedler (1996) has remarked, many new political parties fit well the APEp categorization, this is not the case in all instances: Ciudadanos in Spain and En Marche! in France are perhaps the clearest examples.

${ }^{5}$ We include all APEp that achieved more than $0.1 \%$ of the votes, which is quite comprehensive.

${ }^{6}$ It is important to note that we make no distinctions here on the basis of their ideological position (left vs. right) or the role (government vs. opposition) they play within the party system. This is something we leave for future research.

${ }^{7}$ This is not surprising as (1) micro-state Malta is the only real two-party system in the whole continent and (2) 'consociational' Switzerland is characterized by a very special arrangement (i.e., 'magic formula') that in practice deprives the country from any real partisan competition at the national level (Lijphart, 1999).
} 


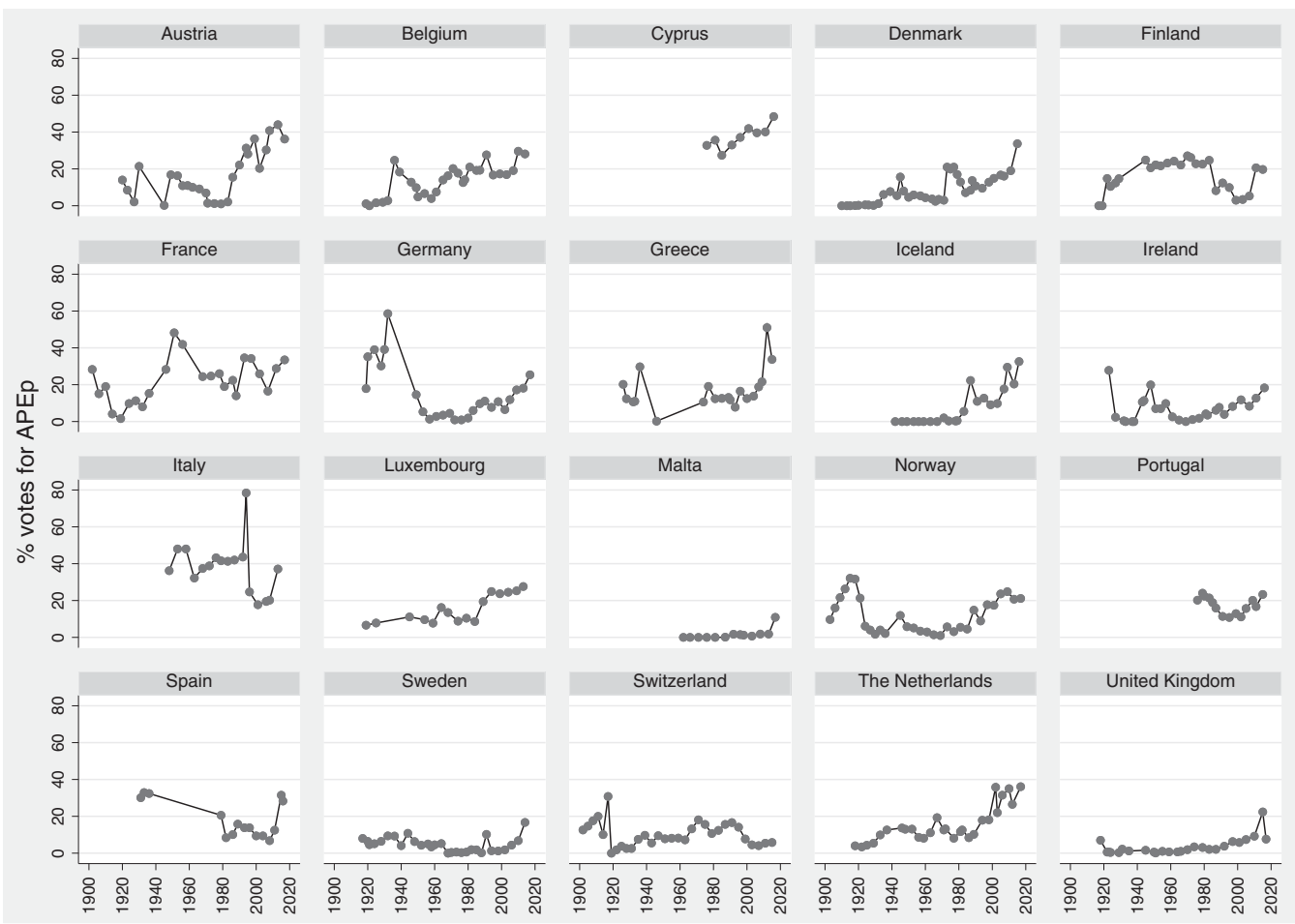

Figure 1. Percentage of votes for APEp in Western Europe, 1900-2017. Source: Own dataset (2020)

democracies the current levels of electoral support for APEp are much lower than during, for instance, the interwar period (1918-1939). ${ }^{8}$

Given the cross-national and cross-temporal variation observed here, and before trying to answer the question on the sources of APEp's support in Western Europe so we can learn how to tackle the specter that is currently haunting this part of the old continent, we will proceed now to revise the factors that, according to the existing literature, could explain the success of this set of parties.

\section{Economic, institutional, sociological change, and electoral support for APEp Economic factors}

The rise of support for APEp experienced during the last decade, and especially in those countries mostly affected by the 2008 Great Recession (e.g., Greece, Spain), has favored the view that economic conditions are mostly responsible for the high levels of support this set of parties has enjoyed in many Western European democracies. Based on the literature that shows how voters reward parties in government when economic conditions are favorable and punish them when the economy performs poorly boosting the opposition (Stegmaier and Lewis-Beck, 2000; Dassonneville and Lewis-Beck, 2019), the recent scholarship has suggested a clear positive relationship between negative macroeconomic factors and support for APEp.

In a first large- $\mathrm{N}$ comparative analysis of the causes of electoral support for extreme-right parties in Western Europe between 1970 and 1990, Jackman and Volpert (1996) found that electoral

${ }^{8}$ Greece, perhaps, is the clearest exception. 
support for this kind of party increases in those countries where the electoral system is proportional and unemployment is high. In a follow-up work including also the 1990s, Golder (2003) found support for the latter, but not the former. Interestingly enough, he also found that high levels of immigration also boost electoral support for extreme-right parties. ${ }^{9}$ The positive relationship between high levels of unemployment (contextual factor), as well as being unemployed (individual factor), and electoral support for the extreme right was also found in Arzheimer's (2009) multi-level study of 18 Western European countries between 1980 and 2002. These findings were clearly in line with Abedi's (2004) work which, using the broader notion of APEp and including both extreme-right and extreme-left parties, found a similar positive relationship between unemployment and support for non-mainstream parties. ${ }^{10}$

More recently, Doležalová's (2015) study of the levels of electoral support for extremist (both left and right) parties in 23 EU member states between 1995 and 2012 also found unemployment to be a major cause. However, and echoing Brückner and Grüner's (2010) ${ }^{11}$ finding of a moderate positive relationship between economic slowdown and support for extreme political forces in Organization for Economic Co-operation and Development countries, they also showed an association between economic recession and the rise of extremism.

Bearing in mind all that has been said, we expect support for APEp to increase in an economic hardship context. ${ }^{12}$ The main reason is that under negative economic conditions voters will be more inclined to support these kinds of parties proposing alternative solutions to their sufferings. In this regard, and following Kayser and Wlezien (2011), we measure economic negative circumstances by using the levels of Gross Domestic Product (GDP) growth. Thus, we hypothesize that

\section{HYPOTHESIS 1a: Economic decline and APEp's electoral support are positively related.}

However, and given the large amount of recent works linking the 2008 global financial and economic crisis with the surge of APEp in the last few years (Lindvall, 2014; Roberts, 2017), it is reasonable to think that what triggers voters to support APEp is not so much the state of the economy per se, but the shock caused by so-called 'big crisis' (e.g., Great Depression and Great Recession) as they combine both financial and economic hardships with cultural and political downturns. To the point that, as it has been shown elsewhere (Achen and Bartels, 2016), voters' punishment might be determined by particular uncontrollable events, for instance, shark attacks, droughts, or floods. In this context, it is also plausible to think that the kind of shocks caused by severe (and global) crises - like the Great Depression or the Great Recession - might lead stressed citizens to behave 'irrationally' and, consequently, support an alternative party. Also, as some scholars have recently pointed out (Fernández-García and Garcia-Luengo, 2019; Rico and Anduiza, 2019; Mols and Jetten, 2016, 2017), it might be the perception that the country is doing poorly economically - rather than the actual economic decline - that make voters feel attracted toward the 'easy solutions to complex problems' proposed by most APEp. For example, recent studies such as the one conducted by Mutz (2018) find that support for Donald Trump in the

\footnotetext{
${ }^{9}$ Jetten et al., focusing on individual economic factors and support for anti-immigration parties, found that 'negative attitudes towards immigrants and support for anti-immigrant parties are observed both among those experiencing relative deprivation and those experiencing relative gratification' (2015: 1). Additionally, they also observed that those with higher resources have a higher probability to support anti-immigrant parties when inequality grows.

${ }^{10}$ At the individual level, however, the findings are contradictory. Some scholars (Norris, 2005; Mudde 2007) find that personal and household income are bad predictors for radical right support, while others find that 'income inequality effect encourages poor people to vote for Radical Right parties' (Han, 2016: 54).

${ }^{11}$ Although they did not control for unemployment.

${ }^{12}$ Given that one could also think of a different causal relationship, and in order to avoid endogeneity, we have decided to lag this and other independent factors (see the 'operationalization' section).
} 
US 2016 presidential elections could be explained by increasing anxiety among high-status groups, rather than pocketbook economic concerns.

In fact, in what can be considered the most comprehensive study of the impact economic and financial crises have on the level of support for extreme-right parties, Funke et al. found that 'policy uncertainty rises strongly after financial crises as government majorities shrink and polarization rises' (2016: 1), especially after the crisis, but often lasting less than 8 years. More recently, but looking at a different period (1900-2016), Dalio et al. (2017) also suggested a clear correlation between economic downturns and support for populist parties.

In a similar vein, but adopting a case-study approach which looked at the sources of populism in several European countries, Kriesi and Pappas (2015) concluded that it was the 2008 economic crisis that led to an increase in the level of support for populist (both left and right) parties. This argument was later confirmed by Kriesi in a work together with Hernández (2016) where they also pointed out that parallel to the decrease of support for established political parties, economic hardship mostly benefited the radical-left, the radical-right, but also other non-mainstream (APEp) parties (e.g., the Greens).

Hernández and Kriesi (2016) clearly show that, unlike what happens under normal economic circumstances, in elections taking place under the context of the 2008 Great Recession, economic voting theories lose explanatory power in favor of more long-term (systemic change) approaches. In their view, big economic crises do accelerate pre-existing de-alignment (as voters perceive that established parties do not represent their interests) and re-alignment (as new social divides gain relevance in order to determine vote choices) processes. Thus,

in contexts like the Great Recession, punishment of the incumbents by the voters is not only likely to occur in much greater proportions, but its consequences are also likely to be longerlasting than the shifts of the voters to the mainstream opposition parties (2016: 204).

The idea, therefore, is that under particular critical economic junctures, like the ones in 1929 or 2008, both economic and political resentment will benefit parties fighting the status quo (Hooghe and Marks, 2018; Roberts, 2017). In other words, and paraphrasing Casal Bértoa and Weber (2019: 234), 'big crises' are like the 'treatment' that causes a 'response' in domestic party politics, namely, the rise of APEp. Thus, and taking into consideration what has been said, we can formulate the following hypothesis:

HYPOTHESIS 1b: During big economic events, the impact of economic variables on support for APEp will be higher than in other time periods.

\section{Institutional factors}

Notwithstanding what has been said, and although the idea of a positive relationship between economic downturns and support for APEp sounds intuitive, the fact that this type of party obtained excellent electoral results in economically growing countries like Poland (Casal Bértoa and Weber, 2019: XXVII-XXX), France, The Netherlands, Austria, or Finland (EEAG, 2017: 60) lead us to think of other possible (non-economic) explanations (Mudde, 2007: 206).

Basically, one can distinguish two types of these 'non-economic' explanations in the literature, namely, institutional and sociological. Posed by the 'cartel party thesis' school, the first type puts the blame on traditional political parties as they are considered to have become, especially since the late 1980s, 'state agencies' failing to represent voters' interests (van Biezen, 2004).

As it follows from Katz and Mair's (1995) seminal work, these two types have been the main reasons why the 'cartelization' of traditional (e.g., conservative, social-democratic, and liberal) political parties has led to an increase in support for APEp. First of all, the 'collusion' of mainstream 
parties, and consequent convergence toward the center of the political spectrum, has made it very difficult for voters to (ideologically) distinguish among them, making important segments of the electorate more susceptible to be attracted to the markedly different policies put forward by APEp. Secondly, the abovementioned move of mainstream parties to the center has also left an important (unrepresented) space at the margins of the ideological spectrum, prone to be occupied by those APEp (Abedi, 2002; Mair, 2002; Morgan, 2013). In other words,

where moderate left and right parties have converged toward centrist positions and may even have cooperated in government coalitions, the chances for 'populist antistatist parties' as well as parties of the 'New Radical Right' [or Left] to be electorally successful rise considerably' (Kitschelt and McGann, 1995: 17, 20-23, 48).

The result has been the appearance of many new parties which, claiming to defend the interests of the people against the 'corrupted' elites (Mudde and Rovira Kaltwasser, 2017), have come to occupy such 'representative void', generally found at the fringes of the political spectrum (Katz and Mair, 2009). ${ }^{13}$ Consequently, we hypothesize that

HYPOTHESIS 2: The higher the electoral fragmentation, the higher the support for APEp.

If, as a result of the process of cartelization by which traditional political parties have withdrawn from society into the state losing its traditional representative function and becoming 'public utilities' (van Biezen, 2004), new parties (the majority of them characterized by an anti-establishment rhetoric) have emerged progressively gaining ground (both in the electorate and in government) at the expense of mainstream ones, then electoral fragmentation could be considered as a good proxy to measure the extent to which traditional (mainstream) political parties are in crisis.

\section{Sociological factors}

Another school of thought, led by Dalton and other American scholars, puts the emphasis instead on sociological - rather than institutional - change (Müller-Rommel, 2016: 4-5). The basic idea behind this line of thought is that the process of globalization and secularization, common to all Western democracies since the late 1970s and especially after the end of the Cold War, has brought important changes in society which, in turn, have led to a decline in what Sartori (1969) called 'the sociology of politics'. In other words, contrary to what - at least until the late 1980 s - had been the norm in Europe, where the structure of inter-party competition in a country was determined by its cleavage structure (Lipset and Rokkan, 1967; Bartolini and Mair, 1990), the decline of - mainly the class and religious - cleavages has led to a process where the appearance of new issues (e.g., migration and corruption) and dimensions of competition (e.g., austerity and Europeanization), less socially rooted, have produced a decrease in party identification, an increased importance of candidate and performance-evaluation and/or valence voting, and an important reduction in electoral stability (Dalton and Wattenberg, 2000; Dalton and Weldon, 2005; Thomassen, 2005).

At the aggregate level, the classic way to measure such decline in the sociological roots of voters' partisan preferences, mostly caused by the declining electoral relevance of traditional cleavage groups, has been Pedersen's index of total electoral volatility (TEV) (see Crewe, 1985;

\footnotetext{
${ }^{13}$ One could also think of an indirect link. Thus, as electoral support for traditional cartelized political parties declines - as a result of their collusion - and voters turn to alternative political forces - either old or new - outside the cartel, the balance of power will become more widespread, leading to an increase in the number of relevant parties and, consequently, the percentage of votes for APEp.
} 
Franklin et al., 1992), traditionally seen also as an indicator of 'electoral realignment' (Pedersen, 1979: 6). For all these reasons, we think that

HYPOTHESIS 3: TEV and support for APEp are positively related.

\section{Institutional and sociological factors}

However, more recently, in what has been labeled as a 'Copernican Revolution' (Casal Bértoa, 2017: 305) or a 'Damascene convergence' (Dalton et al., 2011: 24), Mair came in his posthumous study (2013) to the conclusion that the crisis of representative democracy and the consequent rise of APEp had its cause on the 'mutual withdrawal' of both political parties and voters from the electoral arena.

Thus, and contrary to what could be observed in the so-called 'golden age' of 'mass party' democracy, where both voters and parties were interconnected by a 'representative' chain that went from voters - whose ideological inclinations were anchored in social divisions - to the state through parties, acting as the agents which glued ideological preferences with government policies; now not only voters have deserted political parties as data on declining party membership, trust, and voter turnout clearly show, but also parties have abandoned voters, taking refuge in the state. A simple look at the levels of party financial dependence, over-regulation, and patronage would be more than illustrative (van Biezen and Kopecký, 2014; Mair, 2013). As a result, and taking into consideration that not only voters but also parties should be blamed for the current wave of APEp's success, we formulate a fourth hypothesis combining both schools of thought (i.e., institutional-European and socio-American):

HYPOTHESIS 4a: The higher the electoral fragmentation and volatility, the higher the vote for APEp will be.

In addition, and following the big events argument explained above, we could expect that such an incremental effect of GDP growth in the support for APEp during this time period could expand not just to economic variables, but also to institutional and sociological ones. The argument is the same: the two big economic crises (i.e., Great Depression and Great Recession) will amplify the effect of both the crisis of parties and the crisis of voters.

HYPOTHESIS 4b: During the Great Depression and the Great Recession, we expect a higher and positive impact of electoral fragmentation and volatility on APEp support.

\section{Economic, institutional, and sociological factors: operationalization}

Following the scholarship reviewed in the previous section, we will proceed now to operationalize each of the independent variables. However, and before examining each of them in turn, it is important to note that because we are aware that some of our hypotheses could have a different direction (e.g., the higher the support for APEp, the higher the electoral fragmentation in a party system), and in order to avoid any endogeneity problems, we opted for lagging all the independent variables, not just the economic ones. Doing so, we address the impact that economic, institutional, and sociological factors measured in ' $t-1$ ' (in the previous election year) might have on the levels of support for APEp in time ' $t$ '. Table A2 in the Online Appendix presents descriptive statistics (number of observations, mean, standard deviation, minimum, and maximum) for all of the variables mentioned in this article. 
In order to test for the effect of the economy on the level of support for APEp, we use GDP growth. This is not just due to data availability, but also - and especially - to the central role this indicator has traditionally had when measuring economic performance (Kayser and Wlezien, 2011). Specifically, for each election, we use the level of GDP growth (lagged). GDP data come from Gapminder (2017). ${ }^{14}$

Following Sartori's (1976) classic work, linking the number of parties with the presence of powerful anti-systemic/APEp, we will use Laakso and Taagepera's (1979) standard 'effective number of electoral parties' (ENEP) to capture the extent of the crisis of traditional political parties. Measuring how many parties are in a given election weighted according to size, ${ }^{15}$ this indicator constitutes an excellent proxy to try to measure the extent to which new parties have made a successful breakthrough in a given party system (Taagepera and Shugart, 1989).

Electoral change, or the abandonment of traditional political parties by voters, is measured here by Pedersen's (1979) classic index of TEV, which captures 'the net change within the electoral party system resulting from individual vote transfers' ${ }^{16}$ Given that the recent success of APEp has coincided in time with an increase in the level of 'extra-system' volatility in many European countries (Chiaramonte and Emanuele, 2017), high TEV scores are assumed to show the extent to which voters are swinging their preferences from traditional to new 'anti-political-establishment' in most cases - parties.

All in all, in our models, ENEP attempts to capture the crisis of representative democracy from the parties' points of view, while TEV looks at the voters' perspective. In both cases, the data come from Casal Bértoa (2020).

As we also expect a positive relationship between electoral fragmentation and support for APEp, we control for the disproportionality of the electoral system, calculated on the basis of Gallagher's (1991) 'least square index'. The idea is that because more proportional electoral systems will allow more parties into the party system (Duverger, 1954; Lijphart, 1994), including those with an anti-political-establishment character, the percentage of votes for APEp will be higher the less the disproportionality of the electoral system (see also Fernández-García and Garcia-Luengo, 2019). ${ }^{17}$

Another institutional variable for which we control is that of type of regime (TOR). Ever since the publication of Linz's seminal work on the perils of presidentialism (1990a) and the virtues of parliamentarism (1990b), non-parliamentary regimes have been considered to have negative implications for the healthy functioning of democracy, including increasing the level of support for anti-systemic parties. The idea is that while in parliamentary regimes the head of state is either hereditary or (s)elected either by a super-powerful government, which already assembles the qualified majority usually required for this type of (s)election, or by a compromise with the opposition; in (semi-)presidential regimes the 'double electoral process' gives APEp the possibility to win office or, at least, get the necessary publicity to express their grievances against the establishment. The most recent 2017 French presidential elections, which constituted a

\footnotetext{
${ }^{14}$ For the sake of robustness, we have also used inflation (1960-2017) and unemployment (1990-2017) rates taken from the World Bank's WDI (2017). None of these economic indicators are statistically significant. This is in clear contrast to corruption which, measured with the V-Dem (Coppedge et al., 2018) dataset, is positively related to APEp's support, although very weakly (only at 90\%). Given the latter, but especially important data constraints (e.g., Malta and France, between 1849 and 1898 are missing from the V-Dem "corruption index"), we have opted for excluding these three variables from the main models in the article. Results are available from the authors upon request.

${ }^{15} \mathrm{ENEP}=1 / \Sigma v_{i}{ }^{2}$, where $v_{i}$ is the vote share of party ${ }_{i}$.

${ }^{16} \mathrm{TEV}=1 / 2 \Sigma\left|v_{i, t}-v_{i, t-1}\right|$, where $v_{i, t}$ is the vote share of party ${ }_{i}$ at election $t$ preceded by election ${ }_{t-1}$.

${ }^{17}$ Following Rae (1967) or Taagepera and Shugart (1993), and employing Bormann and Golder's (2013) dataset, we have also used the average district magnitude as an alternative indicator. Given that this measurement is not statistically significant, it is not included in our main models. It should be noted though that data were only available from the period after WWII.
} 
boost for Le Pen's Front National or Melenchon's Unbowed France, constitute a clear example. ${ }^{18}$ We operationalize parliamentary regimes as 1 and (semi-)presidential regimes as $0 .{ }^{19}$

We also control for (other) sociological factors. Using Alesina et al.'s (2003) classic dataset, we introduce time invariant variables that capture the level of sociological fractionalization presented in a particular country, namely, linguistic, ethnic, and religious (Lipset and Rokkan, 1967). The logic behind this control is double. On the one hand, scholars have shown again and again the positive relationship between sociological fractionalization and electoral fragmentation (Cox, 1997; Geys, 2006) as well as the negative association between the former and TEV (Bartolini and Mair, 1990; Bernhard and Karakoc, 2011). On the other hand, we expect higher sociological diversity to foster higher support for APEp in a direct way, given the nativist and anti-immigration character of most of these parties (Boomgaarden and Vliegenthart, 2007). ${ }^{20}$

Finally, we also control for the democratic experience a country has and, in particular, for the time (i.e., years) a democracy has lasted (YoD). While, following Converse (1969), one could expect more consolidated democracies to be vaccinated against anti-political-establishment discourses threatening the democratic system in comparison to new ones, where traditional parties and voters are assumed to have experienced the 'APEp's challenge' less often; the 'cartel party thesis' explained above, according to which party systems in long-standing consolidated democracies have become over-institutionalized, could lead us to think exactly the contrary. ${ }^{21}$

\section{Data and method}

The dataset that we use to test our hypotheses comprises Western European party systems under democratic conditions. We consider a country to be democratic when (1) it has a score of $\geq 6$ in the Polity IV index, (2) universal (male) suffrage elections have been held at least once, and (3) governments are formed with (and rely on) parliamentary support, rather than on the exclusive will of the head of state (Casal Bértoa, 2020). Some countries, such as France or Finland, comprise different periods according to the Republic in question. Other countries, such as Austria or Germany, refer to two different party systems (1st and 2nd Republic or the Weimar and Bonn Republics). Some democracies had to be excluded given the lack of data on electoral results. ${ }^{22}$ The end result is a new dataset with 20 Western European democracies, comprising more than 470 elections between 1849 and 2017 (see Table 1).

Because this is an unbalanced time-series cross-section dataset (Beck and Katz, 1995), containing an average of 24 elections by country (minimum 10 for Cyprus and maximum 34 for Switzerland), we make use of panel data with elections nested in countries, which limits substantially the set of methods for the analysis. In order to solve these problems, we estimate an ordinary least square (OLS) with robust standard errors within the country clusters in order to prevent problems of heteroscedasticity and autocorrelation (see Emanuele et al., 2018). The model estimated is the following one:

$$
\begin{aligned}
\text { APEp support }= & \alpha+\beta(\text { GDP growth })+\beta(\text { ENEP })+\beta(\text { TEV })+\beta(\text { Lsq })+\beta(\text { TOR }) \\
& +\beta(\text { Religiously })+\beta(\text { Linguistic })+\beta(\text { YoD }) e
\end{aligned}
$$

\footnotetext{
${ }^{18}$ In Poland, for example, presidential elections have continuously been the source of APEp, for instance, Party X (Partia X) in 1990, Self-Defence (Samoobrona) in 2005, or Kukiz'15 in 2015 (Casal Bértoa and Guerra, 2018).

${ }^{19}$ The only two presidential regimes in the history of European democracy have been Portugal (in 1918) and Cyprus.

${ }^{20}$ Given the high correlation between ethnic and linguistic fractionalization, we only use the second in our main models. Still, using the former instead of the latter does not change our findings at all.

${ }^{21}$ For the sake of robustness, we also tested the effect of the time (i.e. birth year) a country transited to democracy. No significant relationship between this variable and APEp's support was found.

${ }^{22}$ These are Portugal's 1st Republic (1911-1926), Spain's Restoration (1899-1923), and pre-WWI Greece (1875-1915).
} 
Table 1. Time period and number of elections for the selected countries

\begin{tabular}{lcc}
\hline Country & Period & $\begin{array}{c}\text { Number } \\
\text { of elections }\end{array}$ \\
\hline Austria & $1920-2013$ & 25 \\
Belgium & $1919-2014$ & 29 \\
Cyprus & $1976-2017$ & 10 \\
Denmark & $1910-2015$ & 38 \\
Finland & $1917-2015$ & 26 \\
France & $1849-2017$ & 32 \\
Germany & $1919-2017$ & 25 \\
Greece & $1926-2015$ & 20 \\
Iceland & $1942-2017$ & 23 \\
Ireland & $1923-2016$ & 27 \\
Italy & $1948-2013$ & 17 \\
Luxembourg & $1919-2013$ & 16 \\
Malta & $1962-2017$ & 13 \\
Norway & $1903-2017$ & 31 \\
Portugal & $1976-2015$ & 14 \\
Spain & $1931-2016$ & 15 \\
Sweden & $1917-2014$ & 30 \\
Switzerland & $1896-2015$ & 34 \\
The Netherlands & $1918-2017$ & 28 \\
United Kingdom & $1918-2017$ & 26 \\
\hline
\end{tabular}

Source: Casal Bértoa (2020).

\section{Results}

Figure 2 displays the OLS results for our main models ${ }^{23}$ (see also Table A3 in the Online Appendix). ${ }^{24}$ The graph shows the standardized (standard deviation $=1$ ) independent variables. As we have mentioned, we run various OLSs with country clusters - to address the hierarchical structure of the data - and robust standard errors. Model 1 (see also model 1, Table A3 in the Online Appendix) presents the effect of GDP growth on the electoral success of APEp. Although, following the most recent scholarship (Doležalová, 2015; Brückner and Grüner, 2010), we had expected poor economic conditions to foster electoral gains for APEp (see Hypothesis 1a), but looking at the figure below, we can clearly reject this hypothesis.

Interestingly enough, none of our control variables (models 3, 4, 5, and 6) seems to be significantly related to our dependent variable with one exception: TOR. The latter is moderately (only at 95\%) and negatively related to our dependent variable, meaning that support for APEp is higher in (semi-) presidential than in parliamentary regimes, endorsing Linz's fears regarding the perils of direct presidential elections. All other variables - even if not significant - have the expected sign, confirming that the percentage of vote for APEp is higher in countries with (1) higher religious and linguistic diversity (positive sign), (2) higher disproportionality (negative sign), and (3) younger democracies (see the signs of the coefficients in model 6, the full model, in Table A3).

\footnotetext{
${ }^{23}$ Each horizontal line in Figure 2 represents an independent variable of the model, the point standing for the best estimation of its effect upon the dependent variable, and the line for its $95 \%$ confidence interval. If a confidence interval crosses the vertical line drawn at the origin (zero) of the horizontal axis, the effect of the variable is not statistically significant. If it does not cross it, then the effect is significant and positive, if the point is located at the right, or negative, if located to the left.

${ }^{24} \mathrm{We}$ would like to point out that while we believe that APEp are comparable over time in their specific role as attractors of political support during economic downturns, institutional reforms, and/or sociological changes, we do not mean to claim that these parties would not have changed over the last century (just like all party families have changed, anti-political-establishment or not). These are some of the reasons why we replicated our analyses using a dataset covering only the post-1945 period. All of our results (including interactions with our main independent variables TEV and ENEP) remain exactly the same in terms of direction and just lose statistical significance (although close to be statistically significant at 90 per cent) in the case of the interaction between ENEP and Great Recession ( $p$ value $>0.123$ ) (see Figure Al in the Online Appendix).
} 


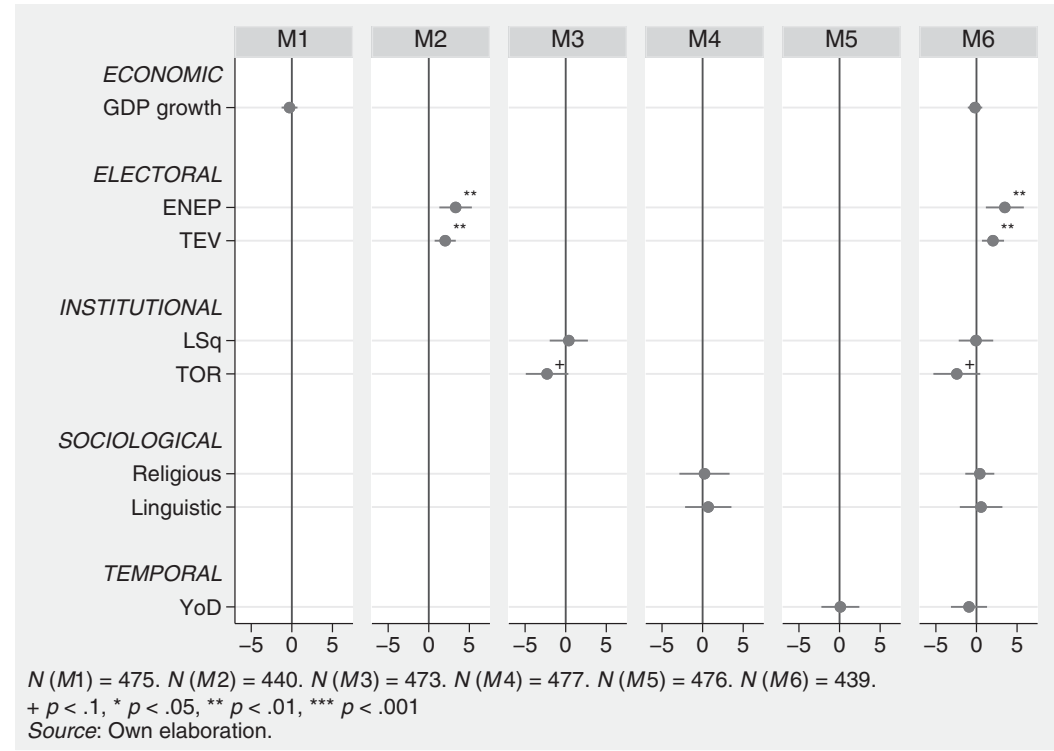

Figure 2. Explaining APEp's support in 20 Western European democracies (1849-2017).

Conversely, both ENEP (traditional parties' crisis) and TEV (voter's change) have positive and very significant impact on the level of electoral support for APEp (see Models 2 and 6), confirming our Hypotheses 2 and 3. This clearly suggests that contrary to the literature that opposes institutional and sociological factors both have contributed to APEp's electoral success. In other words, rather than contradictory, both (European and American) schools of thought are complimentary, as both the crisis of traditional political parties and electoral change are to be blamed for the rise in support for APEp. This is more clearly illustrated in Figure 3, which shows the linear prediction of support for APEp as a function of fragmentation (left) and volatility (right). In particular, every time that an 'effective' electoral party enters the party system, the percentage of votes for APEp will increase in more than 3.5 points. In a similar vein, every time the TEV rises one point the vote for APEp will experience an increase of $2 \%$ (see also models 2 and 6 in Table A3 in the Online Appendix). All in all, Figure 3 clearly supports our Hypothesis 4a.

Following Lindvall (2014), as well as evidence from Figure 1, which shows how support for APEp increased in many European countries mostly after 1929 (e.g., Belgium, Greece, Germany, and Spain) and 2008 (e.g., Denmark, Greece, Iceland, and Spain), but not so much after 1973 (Italy and Denmark are perhaps the only exceptions), we will then limit our comparison to the first two (e.g., Great Depression and Great Recession) crises, ${ }^{25}$ operationalized as dummies in Figure 4.

We test Hypothesis $1 \mathrm{~b}$ in models 4 and 5. Model 1 (replication of model 6 in Figure 2) constitutes the base model. Thus, Figure 4 shows that whereas the Great Depression dummy does not have an effect (neither positive or negative) on the support for APEp (model 2), the Great Recession dummy (model 3) exhibits a high (statistically significant) coefficient (i.e., 11.6; see Table A4 in the Online Appendix). This clearly shows that, in the context of the 2008 Great Recession, voters were more willing to support APEp. In a similar vein, the interaction among GDP growth and both 'big economic events dummies' only results as statistically significant in

\footnotetext{
${ }^{25}$ According to Lindvall (2014: 751), both emerged in the United States, later spreading to Europe, beginning as financial crisis to later turn into full-blown macroeconomic ones.
} 

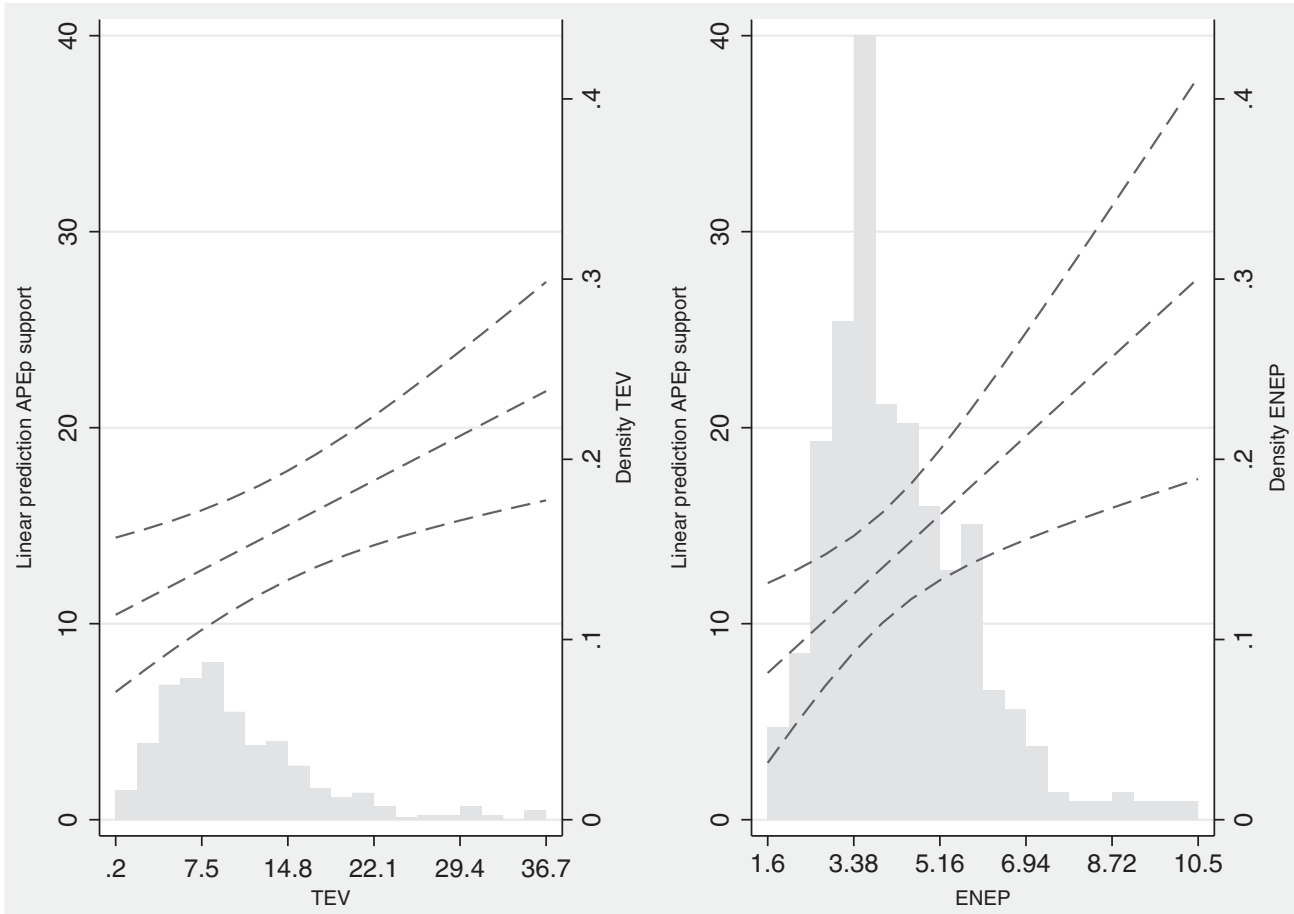

Figure 3. Linear prediction of the percentage of vote for APEp as a function of electoral fragmentation (ENEP) and total electoral volatility (TEV).

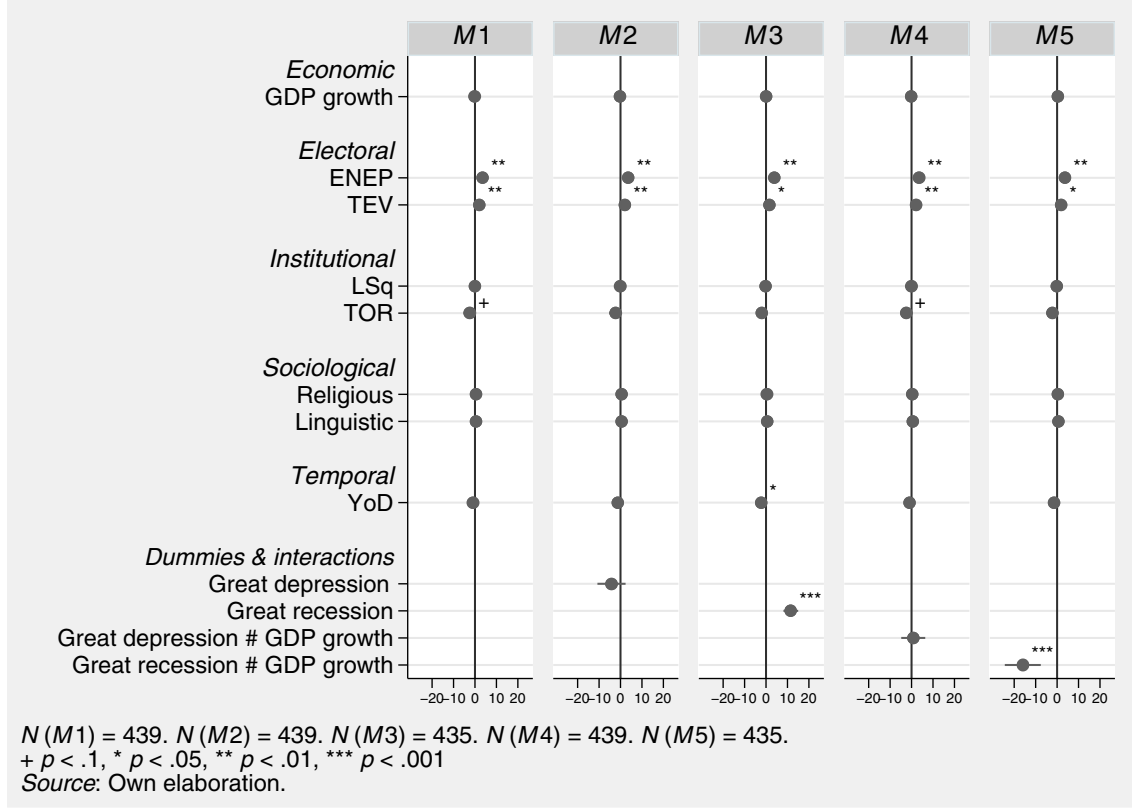

Figure 4. The effect of big economic events on the support to APEp. 

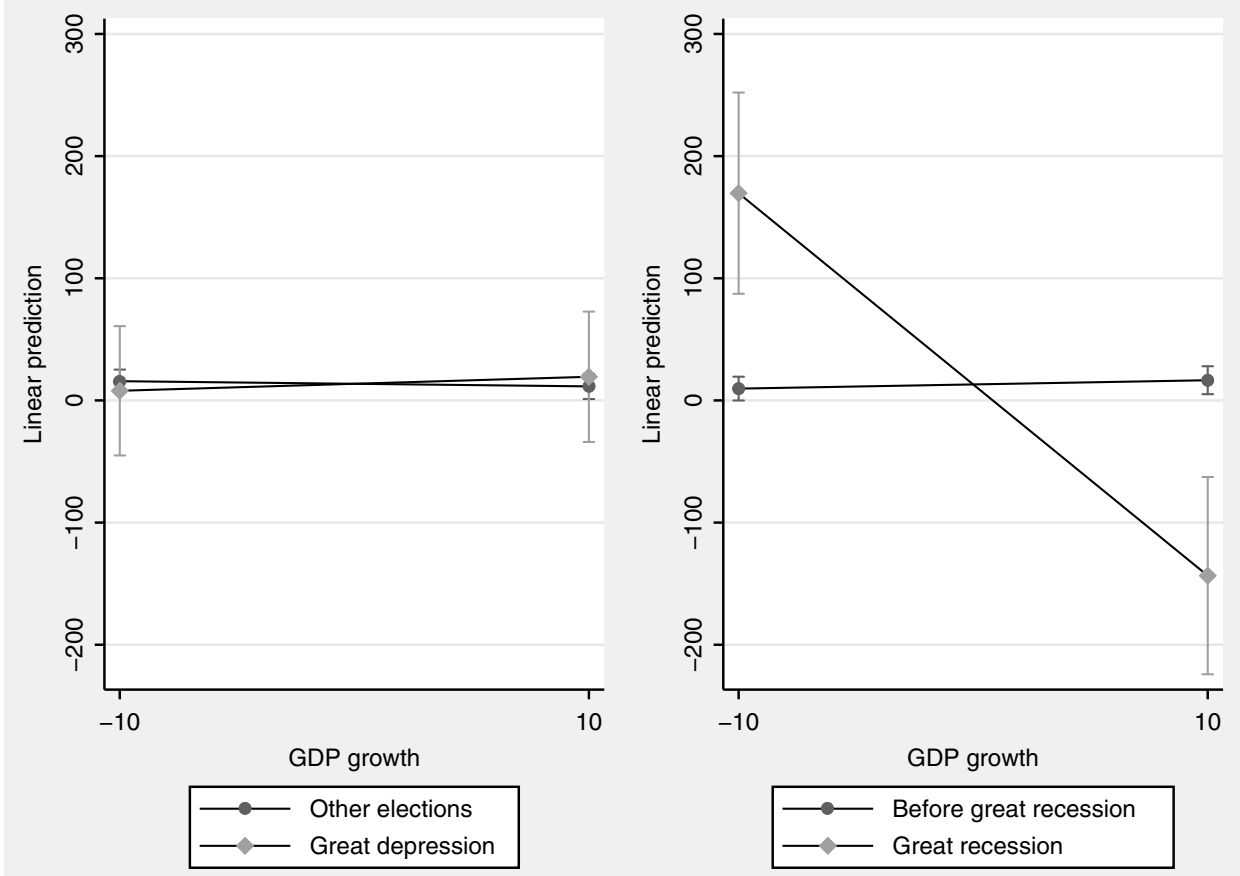

Figure 5. Interaction between big economic events (1929 and 2008) and GDP growth.

the case of the Great Recession (model 5). The sign is negative and the coefficient is extremely high (i.e., -16), suggesting that the lower the GDP growth in Western European democracies since 2008, the higher the share of votes for APEp. Trying to better illustrate the result of both interactions, Figure 5 displays the linear predictions.

Thus, and contrary to all the literature on the effects of the 1929 'Great Crash' (e.g., Klapsis, 2014; de Bromhead et al., 2012), Figure 5 (left) clearly shows that it was not the economic hardships of the Great Depression that led voters to support APEp (e.g., the Nazis in Germany or the Communists in Spain) and, consequently, helped many Western European democracies to collapse. Conversely, however, the right plot in Figure 5 partially confirms that Hypothesis $1 \mathrm{~b}$, as one of the big crises (i.e., the Great Recession), is significantly associated with APEp's success. As Kriesi and Pappas stated it was 'during the Great Recession [that] populism in Europe increased notably' (2015: 323), to the point that 'is currently at its highest level since the late 1930s' (Dalio et al., 2017: 1).

However, if the shock of such a 'big event' like the Great Depression is able to amplify the impact of the economy on APEp's support, we should expect such a big crisis also to amplify the effect of our two main explanatory factors increasing the share of votes for APEp in more fragmented and volatile party systems.

In this context, Figure 6 aims to shed some light on the relationship between our two main explanatory factors (i.e., mainstream parties' crisis and electoral change) and support for APEp during the two big economic crises (i.e., 1929 and 2008). ${ }^{26}$ As it follows from models 1 and 2 in Figure 6, neither fragmentation nor volatility is significantly related to APEp's electoral success during the Great Depression. This is in a way not surprising because no matter how severe

${ }^{26}$ See Table A5 in the Online Appendix for all the statistical models. 


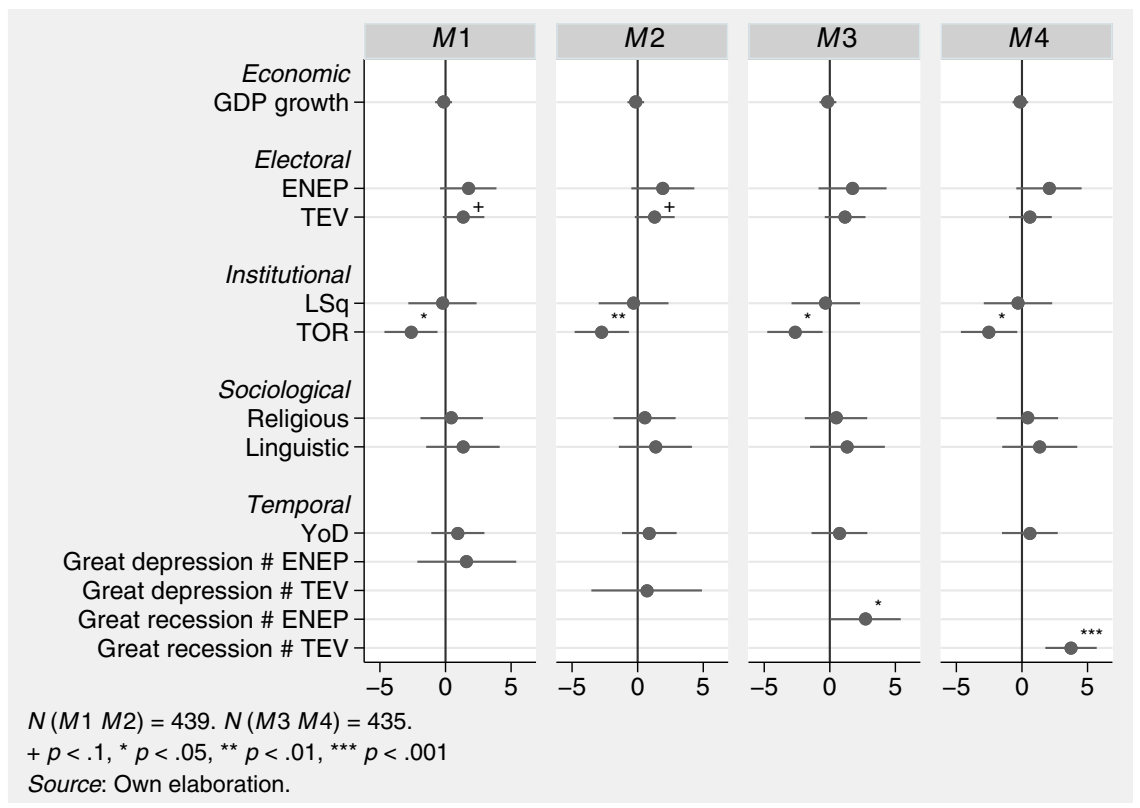

Figure 6. Interaction between big economic events (1929/2008) and fragmentation/volatility.

the 1929 Great Depression was, it took place at a time when both ('mass') parties and (especially class) cleavages were strongest (Bartolini and Mair, 1990; Sartori, 1976).

The situation after 2008 is totally different. In fact, as it follows from models 3 and 4 in Figure 6, the Great Recession helped to significantly increase the impact of both electoral fragmentation and volatility on APEp's support. This seems to confirm Rovira Kaltwasser and Zanotti's conclusion that 'the Great Recession has [simply] amplified pre-existing electoral trends' (2017: 8). Not in vain, the process of party and cleavage decline, and the consequent thawing of Western European party systems, had already started various decades ago (Mair, 1997; Sartori, 1990). What the Great Recession has done, in contrast to what happened during the Great Depression at the height of Lipset and Rokkan's (1967) 'freezing hypothesis' and 'mass parties' golden age', is to make those already weak representative democracies even more vulnerable. In already weakened party systems, both by the crisis of traditional political parties and social change, the shock of the 2008 global financial and economic crisis has lead to the boost of the decline of mainstream parties and the rise of APEp.

Figure 7, by highlighting the interaction effects of the Great Recession dummy, underlines the findings of models 3 and 4 above (see Figure 6) and confirms Hypothesis $4 \mathrm{~b}$ for the case of the Great Recession. As it follows from the figure above, the impact of electoral fragmentation (left) on the percentage of votes for APEp was way higher after the Great Recession than before. And the same can be said in relation to TEV (right).

It is important to note, additionally, that when we take into consideration the whole dataset (1849-2017) fragmentation is more relevant and statistically significant than volatility (see Figure 3), but after the 2008 Great Recession the relationship is totally the opposite, that is, an increase in one TEV unit corresponds to an increase of 3.8 in the percentage of votes for APEps, whereas every time a party enters in the system, APEp support increases 'only' in more than 2.7 points. In other words, during the Great Recession, the impact of electoral fragmentation in APEp support has been one point lower than that of TEV. Consequently, we can conclude that at least for the period compressed between 2008 and 2017, 'sociological change', possibly inspired 

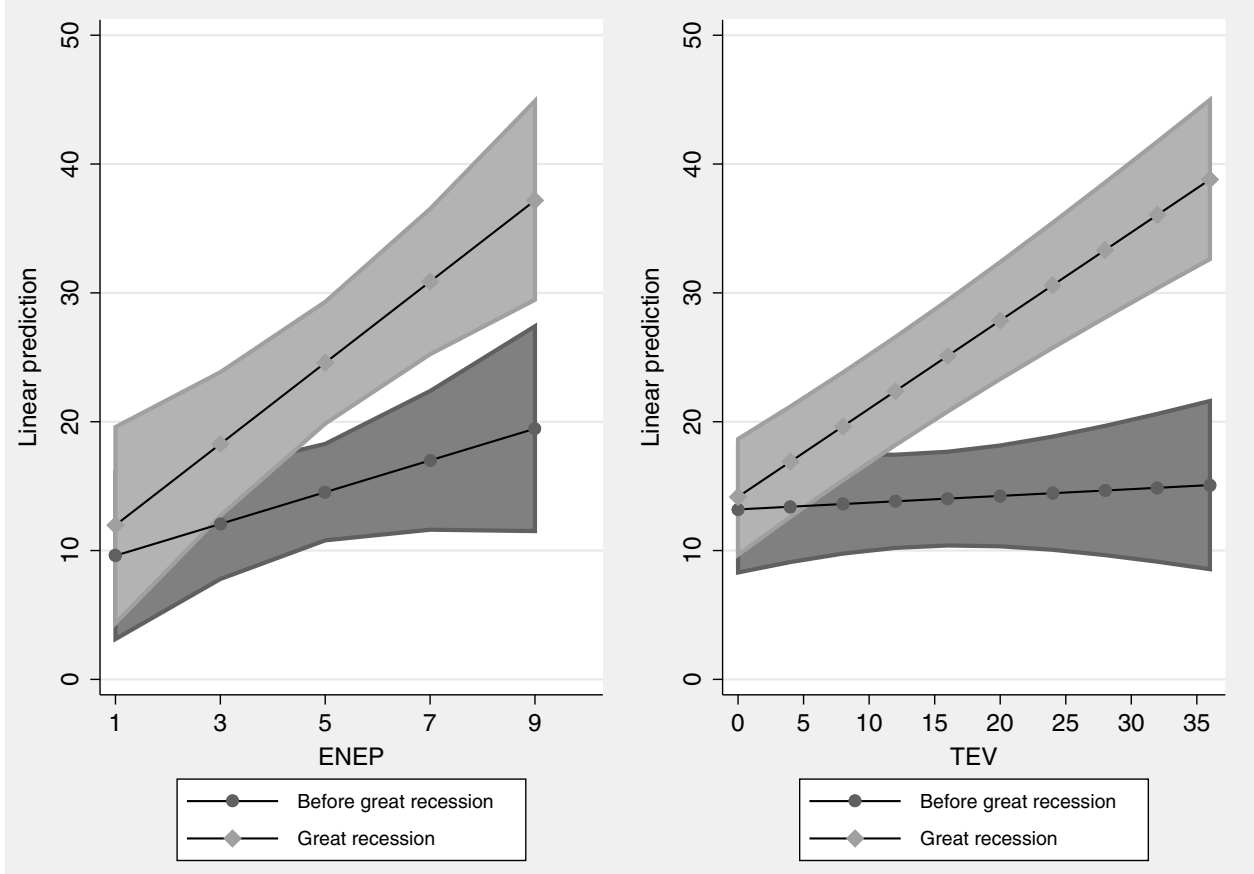

Figure 7. Relationship between fragmentation/volatility and APEp support during the Great Recession.

by the 'the emergence of a transnational cleavage, which has as its core a political reaction against European integration and immigration' (Hooghe and Marks, 2018: 109), has been more responsible for the rise in support for APEp than the crisis of traditional parties themselves.

All in all, it seems clear that 'a single model', as the ones posed by the European (institutional) and American (sociological) schools,

is insufficient to describe the diverse changes occurring in contemporary party systems. The changes affecting these systems are too diverse, ranging from the emergence of new parties to growing anti-party sentiment (Flanagan and Dalton, 1984: 7).

More precisely, and as it follows for our analyses, only a combination of both (institutional and sociological) factors can help us to really understand the rise of APEp and their electoral success (Mair, 2013).

\section{Conclusions}

Support for APEp is on the rise. Never since the turbulent inter-war period has APEp managed to be so successful, not only at the electoral level, but also at the governmental arena. By the end of 2017, APEp governed, either as senior or junior partners, in various Western European democracies. ${ }^{27}$ This has led many scholars, but also journalists and practitioners, to blame the 2008 global and financial economic crisis for APEp's electoral success.

In the current article, we look at the factors that have traditionally been associated with the rise of APEp, namely, economic, institutional, and sociological. Using an original database comprising

\footnotetext{
${ }^{27}$ In others (e.g. Denmark and Portugal), APEp provided parliamentary support but had no ministers.
} 
687 APEp and more than 400 elections between 1849 and 2017 in 20 consolidated Western European democracies, and aware of the limitations, this type of aggregate and statistical studies pose to the disentanglement of any eventual individual mechanism (i.e., the sociological and social psychological processes that fuel support for APEp), we found no relationship between economic performance per se and electoral support for APEp. Instead, our results clearly show that both institutional (electoral fragmentation) and sociological (TEV) factors are significantly associated with APEp's electoral success. In other words, neither the crisis of political parties (European school) nor voters (American school) can be unilaterally blamed for the APEp wave, but the 'mutual withdrawal' of both (parties and voters) from the electoral arena. As Mair put it in his posthumous work, it has been 'the widening gap between rulers and ruled [that] has facilitated the often strident populist challenge that is now a feature of many advanced European democracies' (2013: 18-19).

Remarkably, and notwithstanding many similarities between the 1929 Great Depression and the 2008 Great Recession (Lindvall, 2014), we also found that while the former did not have any significant impact on APEp's success, the latter did. To the point that it not only amplified the positive effect economic decline traditionally has on the vote for APEp, but also clearly boosted the negative influence both party decline and social change were already having on their electoral success. In this context, our results confirm that the 2008 Great Recession, which combines economic, political, and cultural features, is really unique. In this context, the article sheds light on the literature about the causes of support for APEp in general, and populist parties in particular, by emphasizing the need to adopt a historical approach that, on the one hand, looks beyond the current post- 2008 crisis and, on the other hand, goes beyond the traditional economic and cultural unilateral explanations.

Also interesting, especially from the point of view of trying to find possible solutions to the current 'anti-establishment' wave and consequent crisis of liberal democracy, is to point out that while before the 2008 global and financial crisis the crisis of traditional parties, with the 'cartel style' attitudes, had mostly led voters either to seek refuge at the arms of APEp or to abandon the political arena once and for all (Morgan, 2013), after the Great Recession it seems more a matter of social change and the appearance of new cleavages (Hooghe and Marks, 2018).

This is certainly an important point that we need to remember when trying to find a cure to the rise of APEp. Because if increase in the support for APEp is just the symptom of a major problem, that of a democratic system is characterized by the disenchantment of citizens with traditional political parties that have not managed to adapt to a new social reality and have therefore failed to represent their new interests; then the antidote should be neither party bans nor cordon sanitaires, but a new remedy that leads to the revitalization of the traditional parties at the core of the democratic body.

Acknowledgements. We would like to especially thank Professors José Ramón Montero (Universidad Autónoma de Madrid), Cees van der Eijk (University of Nottingham), Russell J. Dalton (University of California), and Dr. Anna Lührmann (University of Gothenburg) for their comments on a previous version of this manuscript as well as the three anonymous reviewers for their valuable comments. We also want to express our gratitude to participants at the IDEA/ODIHR/ NIMD/WFD/REPRESENT International Conference on 'Representation in the Age of Populism' held in Brussels between June 18-20, 2018; as well as to Guillermo Cordero, Andrés Santana, Simona Guerra and the rest of participants at the 2019 Council for European Studies Annual Conference held in Madrid for their helpful comments on a preliminary version of this manuscript.

Supplementary material. To view supplementary material for this article, please visit https://doi.org/10.1017/S1755 773920000260.

\section{References}

Abedi, A. (2002), 'Challenges to established parties: the effects of party system features on the electoral fortunes of antipolitical-establishment parties', European Journal of Political Research 41: 551-583. 
Abedi, A. (2004), Anti-Political Establishment Parties. A Comparative Analyses, London and New York: Routledge.

Alesina, A., A. Devleeschauwer, E. Easterly, S. Kurlat, and R. Wacziarg (2003), 'Fractionalization', Journal of Economic Growth 8(2): 155-94.

Arzheimer, K. (2009), Contextual factors and the extreme right vote in Western Europe, 1980-2002', American Journal of Political Science 53(2): 259-275.

Bartolini, S. and P. Mair (1990), From Identity, Competition and Electoral Availability: the Stabilisation of European Electorates 1885-1985, Cambridge: Cambridge University Press.

Beck, N. and J.N. Katz (1995), 'What to do (and not to Do) with time-series-cross-section-data', American Political Science Review 89(3): 271-293.

Berg-Schlosser, D. and J. Mitchell (2000), Conditions of Democracy in Europe, 1919-1939, London: Palgrave Macmillan.

Bernhard, M. and E. Karakoc (2011), 'Moving West or going South? Economic transformation and institutionalization in postcommunist party systems', Comparative Politics 44: 1-20.

Boomgaarden, H.G. and R. Vliegenthart (2007), 'Explaining the rise of anti-immigrant parties: the role of news media content in the Netherlands', Electoral Studies 26(2): 404-417.

Bormann, N.Ch. and M. Golder (2013), Democratic Electoral Systems around the world, 1946-2011. Electoral Studies 32(2), 360-369.

Brückner, M. and H.P. Grüner (2010), Economic growth and the rise of political extremism: Theory and evidence. Working Paper.

Capoccia, G. (2005), Defending Democracy: Reactions to Extremism in Interwar Europe, Oxford: Oxford University Press.

Carter, E. (2005), The Extreme Right in Western Europe, Manchester: Manchester University Press.

Casal Bértoa, F. (2017), Reseña: Gobernado el vacío: la banalización de la democracia occidental. Revista Española de Ciencia Política 44: 303-306.

Casal Bértoa, F. (2020), Database on WHO GOVERNS in Europe and beyond, PSGo. Available at: whogoverns.eu.

Casal Bértoa, F. and S. Guerra (2018), 'Earthquake or Hurricane? The rise and fall of populist parties in Poland', in S. Wolinetz and A. Zaslove (eds.), Absorbing the Blow. Populist Parties and Their Impact on Parties and Party Systems, London/New York: Rowman and Littlefield.

Casal Bértoa, F. and T. Weber (2019), 'Restrained change: party systems in times of economic crisis', The Journal of Politics 81(1): 233-245.

Chiaramonte, A. and V. Emanuele (2017), 'Party system volatility, regeneration and deinstitutionalization in Western Europe (1945-2015)', Party Politics 23(4), 376-388.

Coppedge, M., J. Gerring, C.H. Knutsen, S.I. Lindberg, S.-E. Skaaning, J. Teorell, D. Altman, M. Bernhard, M. Steven Fish, A. Cornell, S. Dahlum, H. Gjerløw, A. Glynn, A. Hicken, J. Krusell, A. Lührmann, L.L. Marquardt, K. Mcmann, V. Mechkova, J. Medzihorsky, M. Olin, P. Paxton, D. Pemstein, J. Pernes, J. Von Römer, B. Seim, R. Sigman, J. Staton, N. Stepanova, A. Sundström, E. Tzelgov, Y.-T. Wang, T. Wig, S. Wilson, and D. Ziblatt. 2018. 'v-dem [country-year/country-date] dataset v8'. varieties of democracy (v-dem) project. available at https://doi.org/10.23696/vdemcy18.

Converse, P.E. (1969): 'Of time and partisan stability', Comparative Political Studies 2: 139-71

Cox, G.W. (1997), Making Votes Count: Strategic Coordination in the World's Electoral Systems, Cambridge: Cambridge University Press.

Crewe, I. (1985), 'Introduction: electoral change in western democracies: a framework for analysis', in I. Crewe and D. Denver (eds.), Electoral Change in Western Democracies: Patterns and Sources of Volatility. London: Croom Helm.

Dalio, R., S. Kryger, J. Rogers and D. Gardner (2017), Populism: The Phenomenon, Bridgewater: Daily Observations, 203 (226-3030).

Dassonneville, R. and M. Lewis-Beck (2019), 'A changing economic vote in Western Europe? Long-term vs. short term forces', European Political Science Review 11(1): 91-108.

Dalton, R.J. and P.M. Wattenberg (2000), Parties without Partisans: Political Change in Industrial Democracies, Oxford: Oxford University Press.

Dalton, R.J. and S. Weldon (2005), 'Public images of political parties: a necessary evil?' West European Politics 28(5): 931-951.

Dalton, R.J., D.M. Farrell and I. McAllister (2011), Political Parties and Democratic Linkage How Parties Organize Democracy, Oxford, UK: Oxford University Press.

De Bromhead, A., B. Eichengreen, O. Rourke and H. Kevin (2012), 'Right Wing Political Extremism in the Great Depression', University of Oxford, Discussion Papers in Economic and Social History, Number 95.

Doležalová, J. (2015), 'Economic crisis and growth in vote share for extreme left and extreme right parties' Review of Economic Perspectives 15(3): 269-290.

Duverger, M. (1954), Political Parties: Their Organization and Activity in the Modern State, New York: Wiley.

EEAG (2017), The EEAG Report on the European Economy, 'Economic Policy and the Rise of Populism - It's Not So Simple,' CESifo, Munich 2017, pp. 50-66. 
Emanuele, V., A. Chiaramonte and S. Soare (2018), 'Does the iron curtain still exist? The convergence in electoral volatility between Eastern and Western Europe', Government and Opposition 1-19. doi:10.1017/gov.2018.25.

Enyedi, Z. (2016), 'Populist polarization and party system institutionalization: the role of party politics in de-democratization', Problems of Post-communism 63(4): 210-220.

Fernández-García, B. and O. García-Luengo (2019), 'Electoral scenarios of success for anti-establishment political parties in Western Europe: a fuzzyset Qualitative Comparative Analysis', Journal of Contemporary European Studies doi:10.1080/ 14782804.2019 .1567478$.

Foa, R.S., and Y. Mounk (2016), 'The danger of deconsolidation. The democratic disconnect', Journal of Democracy 27 (3): $5-17$.

Flanagan, S.C. and R.J. Dalton (1984), Parties under stress: realignment and dealignment in advanced industrial societies, West European Politics 7(1): 7-23.

Franklin, M., T. Mackie and H. Valen (1992), Electoral Change: Responses to Evolving Social and Attitudinal Structures in Western Countries, Cambridge: Cambridge University Press.

Funke, M., M. Schularick and Ch. Trebesch (2016), Going to extremes: politics after financial crisis, 1870-2014. European Economic Review 88(C): 227-260.

Gallagher, M. (1991), 'Proportionality, disproportionality and electoral systems', Electoral Studies 10(1): 33-51.

Galston, W.A. (2018), 'The populist challenge to liberal democracy', Journal of Democracy 20(2): 5-19.

Gapminder. (2017), https://www.gapminder.org/data/

Geys, B. (2006), 'Explaining voter turnout: a review of aggregate-level research', Electoral Studies 25(4), 637-663.

Golder, M. (2003), 'Explaining variation in the success of extreme right parties in Western Europe', Comparative Political Studies 36(4): 432-66.

Gunther, R., J.R. Montero and J.J. Linz (2002), Political Parties. Old Concepts and New Challenges, Oxford: Oxford University Press.

Han, K.J. (2016), 'Income inequality and voting for radical right-wing parties', Electoral Studies 42: 54-64.

Hanley, D.L. (2002), Party, Society, Government. Republican Democracy in France, Oxford: Berghahn Books.

Hawkins, K. and C. Rovira Kaltwasser (2018), 'Introduction the ideational approach', in K.A. Hawkins, R.E. Carlin, L. Littvay, and C. Rovira Kaltwasser (eds.), The Ideational Approach to Populism. Concept, Theory and Analysis. New York: Routledge, pp. 1-24.

Hernández, E. and H. Kriesi (2016), 'The electoral consequences of the financial and economic crisis in Europe', European Journal of Political Research 55(2): 203-224.

Hobolt, S. and J. Tilley (2016), Blaming Europe? Responsibility Without Accountability in the European Union, Oxford: Oxford University Press.

Hooghe, L. and G. Marks (2018), 'Cleavage theory meets Europe's Crises: Lipset, Rokkan, and the transnational cleavage', Journal of European Public Policy 25(1): 109-135.

Ignazi, P. (1996), 'The crisis of parties and the rise of new political parties', Party Politics 2(4): 549-566.

Ignazi, P. (2017), Party and Democracy: The Uneven Road to Party Legitimacy, Oxford: Oxford University Press.

Jackman, R.W., and K. Volpert (1996), 'Conditions favouring parties of the extreme right in Western Europe.' British Journal of Political Science 26(4): 501-21.

Katz, R.S. and P. Mair (1995), 'Changing models of party organization and party democracy', The Emergence of the Cartel Party, Party Politics 1(1): 5-28

Katz, R.S. and P. Mair (2009), 'The cartel party thesis: a restatement', Perspectives on Politics 7(4): 735-766.

Kayser, M.A. and C. Wlezien (2011), 'Performance pressure: patterns of partisanship and the economic vote', European Journal of Political Research 50(3): 365-394.

Karvonen, L. (1993), Fragmentation and Consensus: Political Organization and the Interwar Crisis in Europe, Boulder, CO: Columbia University Press.

Kitschelt, H. and A.J. McGann (1995), The Radical Right in Western Europe: A Comparative Analysis, Ann Arbor, MI: University of Michigan Press.

Klapsis, A. (2014), Economic Crisis and Political Extremism in Europe: From the 1930s to the present, Economic View, https://doi.org/10.1007/s12290-014-0315-5.

Kriesi, H. and T.S. Pappas (2015), European Populism in the Shadow of the Great Recession, United Kingdom: ECPR.

Laakso, M. and R. Taagepera (1979), 'Effective number of parties. A messure with applications to West Europe', Comparative Political Studies 12 (4): 3-27.

Lane, J-E. and S. Ersson (1994), Politics and Society in Western Europe, London: Sage.

Lijphart, A. (1994), 'Democracies: forms, performance, and constitutional engineering', European Journal of Political Research 25(1), 1-17.

Lijphart, A. (1999), Patterns of Democracy. Government Forms and Performance in Thirty-Six Countries, New Haven and London: Yale University Press.

Lindvall, J. (2014), 'The electoral consequences of two great crises', European Journal of Political Research 53 (4): 747-765. 
Linz, J.J. (1978), The Breakdown of Democratic Regimes: Crisis, Breakdown, and Reequilibration, Baltimore, MD: Johns Hopkins University Press.

Linz, J.J. (1990a), 'The perils of Presidentialism', Journal of Democracy, 1(1): 51-69.

Linz, J.J. (1990b), 'The virtues of Parliamentarism', Journal of Democracy, 1(4): 84-91.

Lipset, S.M. and S. Rokkan (1967), Party Systems and Voter Alignments: Cross National Perspectives, New York: Free Press.

Loomes, G. (2011), Party Strategies in western Europe: Party Competition and Electoral Outcomes, London: Routledge.

Mair, P. (1997), Party System Change. Approaches and Interpretations, Oxford: Oxford University Press.

Mair, P. (2002), 'In the aggregate: mass electoral behaviour in Western Europe, 1950-2000', in H. Kerman (ed.), Comparative Democratic Politics, London: Sage, pp. 122-140.

Mair, P. (2013), Ruling the Void: The Hollowing of Western Democracy, New York and London: Verso Books.

Mols, F. and J. Jetten (2016), 'Explaining the appeal of populist right-wing parties in times of economic prosperity', Political Psychology 37 (2): 275-292.

Mols F and J. Jetten (2017), The Wealth Paradox: Economic Prosperity and the Hardening of Attitudes, Cambridge: Cambridge University Press.

Morgan, J. (2013), Bankrupt Representation and Party System Collapse, University Park: Penn State University Press.

Morlino, L. and F. Raniolo (2017), The Impact of Economic Crisis on Southern European Democracies, The New Protest Parties, London: Palgrave MacMillan.

Mudde, C. (2019), The Far Right Today, Cambridge: Polity Press.

Mudde, C. (2007), Populist Radical Right Parties in Europe, Cambridge: Cambridge University Press.

Mudde, C. and C. Rovira Kaltwasser (2017), Populism. A very short Introduction. Oxford: Oxford University Press.

Mudde, C. and C. Rovira Kaltwasser (2018), Studying populism in comparative perspective: Reflections on the contemporary and future research agenda. Comparative Political Studies, First Online. doi:10.1177/0010414018789490

Müller-Rommel, F. (2016), 'Introduction: political parties in changing democracies', in F. Müller-Rommel and F. C. Bértoa (eds.), Party politics and democracy in Europe: Essays in honour of Peter Mair, Abingdon; New York: Routledge. West European politics, pp. 1-15.

Mutz, D.C. (2018), 'Status threat, not economic hardship, explains the 2016 presidential vote', Proceedings of the National Academy of Sciences 115 (19): E4330-E4339.

Norris, P. (2005), Radical Right: Voters and Parties in the Electoral Market, Cambridge: Cambridge University Press.

Norris, P. and R. Inglehart (2019), Cultural Backlash: Trump, Brexit, and Authoritarian Populism. New York, NY: Cambridge University Press.

Pedersen, M.N. (1979), 'The dynamics of European party systems: changing patterns of electoral volatility', European Journal of political Research 7(1): 1-26.

Powell, B.G. (1981), 'Party systems and political system performance: participation, stability and violence in contemporary democracies', American Political Science Review 75(4): 861-879.

Rae, D.W. (1967), The political Consequences of Electoral Laws. Yale: Yale University Press.

Rama, J. and F. Casal Bértoa (2019), 'Are anti-political-establishment parties a Peril for European Democracy? A longitudinal study from 1950 till 2017', Representation: 1-24.

Rico G and E. Anduiza (2019), 'Economic correlates of populist attitudes: an analysis of nine European Countries in the aftermath of the great recession', Acta Politica 54(3), 371-397.

Roberts, K.M. (2017), 'Party politics in hard times: comparative perspectives on the European and Latin American economic crises', European Journal of Political Research 56: 218-233.

Rovira Kaltwasser, C. and L. Zanotti (2017), 'The comparative (party) politics of the Great Recession: causes, consequences and future research agenda', Comparative European Politics 16(3): 535548.

Sartori, G. (1969), 'From the sociology of politics to political sociology', Government and Opposition 4(2), $195-214$.

Sartori, G. (1976), Parties and Party Systems: A framework for analysis. Cambrige: Cambridge University Press.

Sartori, G. (1990) 'Neither Presidentialism nor Parliamentarism', in J.J. Linz and A. Valenzuela (eds.), Presidential or Parliamentary Democracy, Baltimore-London: John Hopkins University Press.

Schedler, A. (1996), 'Anti-political-establishment parties', Party Politics 2: 291-312.

Stegmair, M. and M.S. Lewis-Beck (2000), 'Economic determinants of electoral outcomes', Annual Review of Political Science 3: 183-219.

Taagepera, R. and M.S. Shugart (1989), Seats \& Votes. New Haven \& London: Yale University Press.

Taagepera, R. and M.S. Shugart (1993), 'Predicting the number of parties: a quantitative model of Duverger's mechanical effect', American Political Science Review, 87(02): 455-464.

Thomassen, J. (2005), The European Voter. A Comparative Study of Modern Democracies, Oxford: Oxford University Press.

Van Biezen, I. (2004), 'Political parties as public utilities', Party Politics, 10(6), 701-722.

Van Biezen, I. and P. Kopecký (2014), 'The cartel party and the state', Party Politics 20(2), 170-182.

Van Kessel, S. (2015), Populist Parties in Europe: Agents of Discontent? Basingstoke: Palgrave Macmillan.

Van Spanje, J., and W. Van Der Brug (2007), 'The Party as Pariah: the exclusion of anti-immigration parties and its effect on their ideological positions', West European Politics 30(5): 1022-1040. 
Vossen, K. (2003), Vrij vissen in het Vondelpark. Kleine Politieke Partijen in Nederland 1918-1940. Amsterdam: Wereldbibliotheek. Available at http://resources.huygens.knaw.nl/repertoriumkleinepolitiekepartijen/Partijen.

Wolinetz, S. and A. Zaslove (2018), Absorbing the Blow. Populist Parties and their Impact on Parties and Party Systems, London-New York: ECPR press.

World Bank Dataset. (2017), Online access: https://data.worldbank.org/.

Zulianello, M. (2019), Anti-System Parties. From Parliamentary Breakthrough to Government, London: Routledge.

Cite this article: Casal Bértoa F and Rama J (2020). Party decline or social transformation? Economic, institutional and sociological change and the rise of anti-political-establishment parties in Western Europe. European Political Science Review 12, 503-523. https://doi.org/10.1017/S1755773920000260 